\title{
Risk factors associated with bulk tank standard plate count, bulk tank coliform count, and the presence of Staphylococcus aureus on organic and conventional dairy farms in the United States
}

\author{
K. M. Cicconi-Hogan, ${ }^{* 1}$ M. Gamroth, $†$ R. Richert, $¥$ P. L. Ruegg, $\ddagger$ K. E. Stiglbauer, $†$ and Y. H. Schukken* \\ ${ }^{*}$ Department of Population Medicine and Diagnostic Sciences, Cornell College of Veterinary Medicine, Cornell University, Ithaca, NY 14853 \\ †Department of Animal Sciences, Oregon State University, Corvallis 97331 \\ ‡Department of Dairy Science, University of Wisconsin-Madison, Madison 53706
}

\begin{abstract}
The purpose of this study was to assess the association of bulk tank milk standard plate counts, bulk tank coliform counts (CC), and the presence of Staphylococcus aureus in bulk tank milk with various management and farm characteristics on organic and conventional dairy farms throughout New York, Wisconsin, and Oregon. Data from size-matched organic farms $(\mathrm{n}=192)$, conventional nongrazing farms $(\mathrm{n}=64)$, and conventional grazing farms $(\mathrm{n}=36)$ were collected at a single visit for each farm. Of the 292 farms visited, 290 bulk tank milk samples were collected. Statistical models were created using data from all herds in the study, as well as exclusively for the organic subset of herds. Because of incomplete data, 267 of 290 herds were analyzed for total herd modeling, and 173 of 190 organic herds were analyzed for the organic herd modeling. Overall, more bulk tanks from organic farms had Staph. aureus cultured from them (62\% of organic herds, $42 \%$ conventional nongrazing herds, and $43 \%$ of conventional grazing herds), whereas fewer organic herds had a high CC, defined as $\geq 50 \mathrm{cfu} / \mathrm{mL}$, than conventional farms in the study. A high standard plate count $(\times 1,000 \mathrm{cfu} / \mathrm{mL})$ was associated with decreased body condition score of adult cows and decreased milk production in both models. Several variables were significant only in the model created using all herds or only in organic herds. The presence of Staph. aureus in the bulk tank milk was associated with fewer people treating mastitis, increased age of housing, and a higher percentage of cows with 3 or fewer teats in both the organic and total herd models. The Staph. aureus total herd model also showed a relationship with fewer first-lactation animals, higher hock scores, and less use of automatic takeoffs at milking. High bulk tank CC was related to feeding a total mixed ration and using natural service in nonlactating
\end{abstract}

Received December 19, 2012.

Accepted September 8, 2013.

${ }^{1}$ Corresponding author: kmc277@cornell.edu heifers in both models. Overall, attentive management and use of outside resources were useful with regard to $\mathrm{CC}$ on organic farms. In all models except the organic CC model, we observed an association with the average reported somatic cell count from 3 mo before the herd visit, indicating that many of the regularly tested milk quality parameters are interconnected. In conclusion, we found that conventional and organic farms are similar in regard to overall herd management, but each grazing system faces unique challenges when managing milk quality.

Key words: dairy, milk quality association, management, organic

\section{INTRODUCTION}

The rapid growth of the organic dairy industry has made research regarding organic milk quality and management practices essential. The resulting increase in certified organic dairy animals and production of organic dairy products is a consequence of a surge in consumer interest concerning animal welfare and the environmental impact of conventional dairy farming (Sundrum, 2001). The perception among consumers is that organically produced milk is healthier or of better quality (Yiridoe and Bonti-Ankomah, 2005), but previous research has found little difference regarding milk quality between organic and conventional farms (Rosati and Aumaitre, 2004; Sato et al., 2005).

Examining and monitoring bulk tank milk on a dairy farm is a useful and efficient method of assessing the quality of milk that the farm is producing. High levels of bacteria in raw milk can adversely affect the quality and shelf life of pasteurized milk (Schukken et al., 2003; Jayarao et al., 2006). Several tests are regularly used to assess the quality of bulk tank milk, such as SCC, SPC, laboratory pasteurized count, and coliform count (CC). Dairy processors use these tests to determine if their clients' products are high quality, and to evaluate whether milk is adequate for distribution and consumption. 
The SPC, also known as the plate loop count, assesses the bacterial density in the milk and estimates the number of aerobic bacteria present per milliliter of milk. Standard plate count is an excellent way to assess management and milk quality, as reported in previous research and milk quality management recommendations (van Schaik et al., 2002; Jayarao et al., 2004; Schroeder, 2009). A high bulk tank SPC can be the result of bacteria from unclean milking equipment, milk from cows with subclinical or clinical mastitis, or contamination from dirty udders (Murphy and Boor, 2000). The regulatory cut-off for SPC in the United States is $100,000 \mathrm{cfu} / \mathrm{mL}$, which is also in accordance with the European Union standards.

Staphylococcus aureus is a contagious mastitis pathogen that can cause an IMI, which has a major effect on milk production and bulk tank SCC (Keefe, 2012). Because Staph. aureus IMI cause an increase in SCC at the cow level, Staph. aureus is positively associated with an increase in the bulk tank SCC. Staphylococcus aureus can spread easily from animal to animal in several ways - by milking units, though improper milking or handling, or lack of glove use, to name a few. Although methicillin-resistant Staph. aureus is one of the most well-known human pathogens, it does not appear to be a major issue in bulk tank milk in the United States [K. M. Cicconi-Hogan, N. Belomestnykh (Cornell University, Ithaca, NY), M. Gamroth, P. L. Ruegg, L. Tikovsky (Boehringer Ingelheim Vetmedica Inc., St. Joseph, MO), and Y. H. Schukken; personal communication; Haran et al., 2012]. Because of the potential effect that Staph. aureus has on milk quality and the significantly higher numbers of organic bulk tanks with Staph. aureus found in this study (Cicconi-Hogan et al., 2013), we felt that the presence of this organism was important to fully understand.

Coliform bacteria found in bulk tank milk, such as Escherichia coli and Klebsiella spp., are usually indicative of fecal contamination, often from soiled udders or teats (Hogan and Smith, 2003) and may occasionally be from a mastitis cow shedding high counts of these coliform bacteria. Although there is no regulatory limit on the amount of coliforms that can be present in raw milk, the Grade "A" Pasteurized Milk Ordinance (Food and Drug Administration, 2009) requires pasteurized milk to have a $\mathrm{CC} \leq 10 \mathrm{cfu} / \mathrm{mL}$. Other research has used $\leq 50 \mathrm{cfu} / \mathrm{mL}$ as the proposed cutoff for "good quality" in regard to coliforms in raw milk (Jayarao et al., 2004). When the SPC of a sample is below the regulatory limits, most coliforms will be removed from the milk by pasteurization before the milk is consumed. Occasionally, in the case of raw milk consumption or a pasteurization failure, coliforms in the milk can lead to severe human disease. Shiga toxin-producing E. coli
O157:H7, which has been isolated from bulk tank milk (Karns et al., 2007), can cause severe hemorrhagic diarrhea in humans.

Previous analyses from our research determined that CC was lower on organic (ORG) farms and that Staph. aureus was higher on ORG farms compared with the conventional (CON) herds in our study (CicconiHogan et al., 2013; Stiglbauer et al., 2013). Thus, CC and the presence of Staph. aureus were natural choices for further investigation. Although several studies have assessed bacterial milk quality and determined associations of bacterial counts with management factors, few have focused on the organic dairy population in the United States.

The objective of this study was to evaluate the relationship between management practices and bulk tank SPC, CC, and the presence of Staph. aureus for all herds involved in the study and specifically for the subset of organic herds. The aim was to identify management characteristics that are associated with good bacterial milk quality and that can be used to define best management practices for either conventional or organic dairy farms or both.

\section{MATERIALS AND METHODS}

\section{Recruitment and Herd Selection}

Our research team has collected longitudinal and cross-sectional data on 292 organic and frequency matched conventional dairy farms and reported on management characteristics (Stiglbauer et al., 2013), the use and role of veterinarians within these populations (Richert et al., 2013), and associations of management with SCC (Cicconi-Hogan et al., 2013); recruitment and herd inclusion criteria are described therein. Briefly, ORG herds selected for inclusion had a minimum of 20 adult cows and had been shipping organic milk for at least 2 yr. Included CON farms were within a 50-mile radius of an ORG farm and had a minimum of 20 adult cows. Dairy herds in New York (NY), Oregon (OR), and Wisconsin (WI) were visited between March 2009 and May 2011. A total of 192 ORG herds and 100 CON herds were frequency matched based on herd size and location. In New York, $72 \mathrm{ORG}$ and $25 \mathrm{CON}$ farms were visited; in Wisconsin, 96 ORG and $51 \mathrm{CON}$ farms were visited; and in Oregon, 24 of both ORG and CON farms were visited.

\section{Questionnaire and Data Collection}

The study questionnaire was modified from previously published survey instruments (Zwald et al., 2004; Pol and Ruegg, 2007). It was reviewed by professional 
survey developers and tested with organic and conventional dairy farmers in each state before the beginning of the study. Farmers were asked to refer to all available records to ensure accuracy of answers. Recall was generally limited to the 12 mo before the herd visit or less. More detailed questionnaire information can be found in Stiglbauer et al. (2013).

In each state, a single member of the study team conducted all interviews. Standardization of data collection among the locations was ensured by monthly conference calls. Data collection methods were consistent across the 3 sites, as described by Richert et al. (2013). For most of the visited herds, the individual directly responsible for animal care was interviewed.

Body condition scoring, udder hygiene, and hock scoring were done by the interviewer on all farms. The process for choosing what animals were scored was described in detail by Cicconi-Hogan et al. (2013). Briefly, a representative sample of a minimum of 50 lactating cows or $20 \%$ of the herd was scored, whichever was larger. All cows were scored on farms with fewer than 50 cows. A representative sample of dry cows was also scored, with 20 dry cows or $20 \%$ scored, or all dry cows if there were fewer than 20. Body condition was evaluated using an accepted scoring method with provided guidelines for examining the hooks, pins, and sacral and tail head ligaments (Ferguson et al., 1994). Udder hygiene was assessed on a 4-point system (Schreiner and Ruegg, 2003). Hock scores were assessed using a 3-point system developed at Cornell University (Fulwider et al., 2007). All scoring forms can be found at http:// milkquality.wisc.edu/wp-content/uploads/2011/10/ Reference-Guides-for-Scoring.pdf or at http://dx.doi. org/10.3168/jds.2012-6505.

\section{Bulk Tank Milk Sample Collection and Testing}

Bulk tank milk samples were collected by study personnel at 290 farms. Bulk tanks were agitated for a minimum of $5 \mathrm{~min}$ and samples were taken directly from the tank with a sterile sampler. Samples were put on ice and transported to Quality Milk Production Services at Cornell University (Ithaca, NY) for analysis. Two farmers in the study requested that their bulk milk not be analyzed and therefore were not included in the bulk tank milk analysis.

The milk quality methods and associated references are described in more detail in Cicconi-Hogan et al. (2013). The SPC was assessed using the plate loop count method described by Wehr and Frank (2004). Briefly, $0.0001 \mathrm{~mL}$ of raw milk was plated on Standard Methods agar. Plates were aerobically incubated at $32^{\circ} \mathrm{C}$ for $48 \mathrm{~h}$ and counted. The $\mathrm{CC}$ was assessed using $3 \mathrm{M}$ Petrifilm (3M, St. Paul, MN). One milliliter of raw milk was added to a sheet of Petrifilm. The sample was incubated aerobically for $24 \mathrm{~h}$ at $35^{\circ} \mathrm{C}$ and the colonies were counted. Farms were defined as having a high $\mathrm{CC}$ if they tested $\geq 50 \mathrm{cfu} / \mathrm{mL}$ based on prior research (Jayarao et al., 2004). The presence of Staph. aureus was assessed using the standard methods from Hogan et al. (1999). In short, $0.5 \mathrm{~mL}$ of raw milk was plated on a blood agar plate and incubated for $48 \mathrm{~h}$ at $37^{\circ} \mathrm{C}$. Colonies were determined to be Staph. aureus by assessing for hemolysis, a positive coagulase test, and a positive catalase test.

Additionally, all bulk tank milk samples were analyzed for the presence of foodborne pathogens Salmonella spp., Listeria monocytogenes, and Shiga toxinproducing E. coli. Samples were also tested for the presence of Mycoplasma bovis, bovine virus diarrhea virus, a modified mastitis bacteria count, and antibodies to Mycobacterium avium ssp. paratuberculosis (Johne's disease). Samples were tested for SCC, SPC, laboratory pasteurized count, CC, E. coli count, and butterfat and protein percentages at Dairy One Cooperative (Ithaca, NY).

\section{Statistical Analysis}

Predictor Variables. All statistical analyses were performed using SAS version 9.2 (SAS Institute, 2008). Dairy production system (ORG, CON) and grazing information were combined to create a new predictor variable, grazing system, which had 3 levels: (1) ORG, (2) conventional grazing (CON-GR), and (3) conventional nongrazing (CON-NG). Grazing was defined as herds where lactating cows obtained $\geq 30 \%$ of DMI from pasture during the grazing season. Grazing system, herd size category (0-99 cows, 100-199 cows, $\geq 200$ cows), and location (NY, OR, WI) were associated with the design of the study and were forced into all multivariable models.

Predictor variables assessed for inclusion in the models were selected based on similarity to variables described in the meta-analysis of Dufour et al. (2011) and the SCC analysis of the current study, as reported by Cicconi-Hogan et al. (2013). General farm characteristics that were assessed were as follows: average age of primary adult housing in years; percentage of firstlactation cows on the farm; number of years the farmer had been in the dairy industry; seasonality, computed using the formulas $\sin [2 \pi \times$ (day of year of herd visit/365) $]$ and $\cos [2 \pi \times$ (day of year of herd visit/365)], where $\pi=3.14$; percentage of problem breeders in the past 12 mo (defined as animals that had been removed from the herd due to failure to conceive, animals that had been removed from the breeding population by labeling her "do not breed" because of failure to conceive, 
or animals that were 9 mo postpartum and not yet pregnant); estimated calving interval in days (provided by herd record systems or estimated by adding $60 \mathrm{~d}$ to the estimated lactation length); amount of milk produced per cow per day $(\mathrm{kg})$; type of milking facility (pit parlor, flat or walkthrough parlor, tiestall or stanchion, other type of facility); presence of Staph. aureus in the bulk tank at the time of the visit (yes, no); average reported SCC of milk shipped in the 3 mo before the herd visit; and average reported SPC of milk shipped in the 3 mo before herd visit $(<1-7,000 \mathrm{cfu} / \mathrm{mL}, 8,000-32,000$ $\mathrm{cfu} / \mathrm{mL}, \geq 33,000 \mathrm{cfu} / \mathrm{mL}$ ). General management variables were as follows: mean BCS, mean hock score, mean udder hygiene score, use of natural service for nonlactating heifers (none versus at least some use of $\mathrm{AI}$ ), use of natural service for adult cows (none versus at least some use of $\mathrm{AI}$ ), use of a dedicated calving area separate from all other cows (yes, no), farmer reported improved laneways (yes, no), use of a segregation unit or bucket milker or during milking (yes, no), number of people who treat mastitis, written herd health and treatment records (yes, no), regular veterinarian visits (yes, no), use of vaccinations in adult cows (yes, no), use of vaccinations in calves under $90 \mathrm{~d}$ of age (yes, no), use of a nutritionist (yes, no), use of DHIA (yes, no), use of anionic salts in transition cow diets (yes, no), frequency of bulk tank cultures taken per year (never, monthly, quarterly, other times per year), routinely checking postpartum cows (yes, no), use of a California Mastitis Test (yes, no), housing sick cows separately from healthy cows (yes, no), transferring cows to an alternate farm (yes, no), introduction of new dairy cows or heifers in the past 12 mo (yes, no), percent of herd with 3 or fewer teats, percent of the herd that had at least one quarter of which milk was segregated from the bulk tank, number of times milked per day, use of a predipping solution (yes, no), use of a postdipping solution (yes, no), use of gloves during milking (yes, no), use of automatic take offs (yes, no), number of milkers on the farm, forestripping before milking (yes, no), number of milking units $(0-10,11-20, \geq 20)$, use of TMR (yes, no), and the amount of grain fed per cow per day $(\mathrm{kg})$. Grazing-specific variables that were assessed for the organic models only were as follows: number of acres used for pasture, use of grazing (yes, no), average percentage of DMI from pasture, percent of pasture that has been improved in the past $7 \mathrm{yr}$, and use of rotational grazing (yes, no).

To measure the level of external support a farmer was using, several variables were combined to create a new variable, referred to as external input score (EIS), described in more detail in Cicconi-Hogan et al. (2013). The EIS variable was created by adding the scores of several management variables, resulting in a scale that ranged from 0 to 10 . The variables used for the EIS score were use of nutritionist (yes, no), regular use of a veterinarian (yes, no), use of DHIA (yes, no), use of anionic salts in transition cow diets (yes, no), vaccination of cows (yes, no), vaccination of calves (yes, no), regular pregnancy checks (yes, no), a written record of herd health events (yes, no), any use of natural service in nonlactating heifers (yes, no), and any use of natural service in lactating cows (yes, no).

Statistical Model Building. Data were analyzed from 290 out of 292 farms. Because of missing explanatory variable information, 267 of 290 herds were analyzed in the total herd models, and 173 of 190 organic herds were analyzed for the organic herd models. Outcome variables analyzed were SPC from the bulk tank, the presence of Staph. aureus in the bulk tank, and the CC of the bulk tank milk. The presence of Staph. aureus was analyzed as a binary variable (yes, no). The distribution of the SPC and $\mathrm{CC}$ were both truncated on the left at 0 and skewed to the right. The SPC was transformed to $\log _{10} \mathrm{cfu} / \mathrm{mL}$ (hereafter, LSPC) and reported as a geometric mean. The CC was dichotomized, based on previous research and milk quality recommendations (Jayarao et al., 2004; Schroeder, 2009; Elmoslemany et al., 2010), at either $\leq 50$ $\mathrm{cfu} / \mathrm{mL}(=0)$ or $>50 \mathrm{cfu} / \mathrm{mL}(=1)$.

The distributions of the individual predictor variables were analyzed by PROC UNIVARIATE (SAS Institute, 2008). When appropriate, predictor variables were categorized into 3 groups based on the 25th and 75 th percentiles $(0-25 \%, 26-75 \%, 75-100 \%)$. Two different subsets of data were used in creating 6 regression models, one using information from all herds with complete information and one using only information from organic herds with complete information, to test for associations with various predictor variables. Three of the models used data from all herds in the study (SPC total herd model, Staph. aureus total herd model, and coliform total herd model) and 3 of the models used data from all organic herds in the study (SPC organic herd model, Staph. aureus organic herd model, and coliform organic herd model). Variable selection was done according to the method described by Dohoo et al. (2010).

The Staph. aureus models and the CC models were analyzed by logistic regression, using PROC LOGISTIC (SAS Institute, 2008). The general logistic regression model for the total herd models was formulated as

$$
\begin{aligned}
\ln \left[\frac{Y}{1-Y}\right] & =\beta_{0}+\beta_{1} \text { Grazing System } \\
& +\beta_{2} \text { Herd Size Category }+\beta_{3} \text { Site }+\beta_{k} X_{k}+\ldots+\varepsilon
\end{aligned}
$$


where $Y=$ binary outcome variable, $\beta_{0}=$ intercept term, $\beta_{k}=$ regression coefficient, $X_{k}=$ predictor variable, and $\varepsilon=$ error term.

The LSPC models were analyzed by linear regression, using PROC MIXED (SAS Institute, 2008). The general form of the linear model used for the LSPC models was formulated as

$$
\begin{aligned}
\mathrm{LSPC} & =\beta_{0}+\beta_{1} \text { Grazing System } \\
& +\beta_{2} \text { Herd Size Category }+\beta_{3} \text { Site }+\beta_{k} X_{k}+\ldots+\varepsilon,
\end{aligned}
$$

where $\beta_{0}=$ intercept term, $\beta_{k}=$ regression coefficient, $X_{k}=$ predictor variable, and $\varepsilon=$ error term.

Model selection was performed in 3 steps. First, each predictor variable was assessed for unconditional associations by logistic regression for $\mathrm{CC}$ or the presence of Staph. aureus or by linear regression for LSPC. Then, unconditionally associated variables (using a cutoff of $P \leq 0.25$ ) were separated into groups (general farm characteristics, general management characteristics) and were included for selection for multivariable submodels. Predictor variables with a $P \leq 0.25$ were selected for inclusion in the final model, in addition to the design variables (grazing system, herd size category, and site) that were always included in the multivariable models. Finally, all predictor variables that remained in the submodels were selected for a final multivariable model, analyzed using PROC LOGISTIC or PROC MIXED (SAS Institute, 2008). The final multivariable model was constructed using backward selection techniques, with the design variables grazing system, site, and herd size category forced into the model. Predictor variables significant at $P \leq 0.10$ and all design variables remained in the final multivariable model. Additionally, alternative forms of each model were built to assess whether SCC was influencing the outcome variables or the outcome variables were driving the
SCC; alternative models were built with SCC removed and compared with the original models.

The model building process used for the organic herd models was identical to that used for building the total herd models but excluding grazing system as a design variable and including the specified grazing variables for analysis.

\section{RESULTS}

\section{Descriptive Outcome Variable Results}

Basic herd demographic information (average herd size, SCC, and milk production per cow per day) and descriptive information of the outcome variables can be found in Table 1. The average herd size was 65.5 adult cows. The geometric mean of the SCC was 191,000 cells/mL for all herds, and 182,000 cells/mL, 166,000 cells/mL, and 195,000 cells/mL for CON-NG, CON-GR, and ORG farms, respectively. Average milk production ranged from $19.5 \mathrm{~kg} / \mathrm{cow}$ per day (ORG) to $27.9 \mathrm{~kg} /$ cow per day (CON-NG), with a mean of $21.2 \mathrm{~kg}$ for all herds. The geometric mean of the SPC $(\times 1,000$ $\mathrm{cfu} / \mathrm{mL}$ ) was 5.19 , with a range of 1 to $3,981,000 \mathrm{cfu} /$ mL. A total of $55 \%$ of all herds had a bulk tank that was positive for Staph. aureus. Sixty-two percent of all ORG herds, compared with $41 \%$ of CON-NG and $42 \%$ of CON-GR herds, were positive for Staph. aureus. Twenty-nine percent of CON-NG and $25 \%$ of CON-GR farms had a high CC, compared with $12 \%$ of ORG herds.

\section{Standard Plate Count}

Final SPC Total Herd Model. A total of 18 variables were significant at $P \leq 0.25$ in the univariate analysis. After grouping the variables as either general farm characteristics or management characteristics,

Table 1. Descriptive information regarding herd size, average bulk tank SCC, milk production, in addition to the outcome variables of SPC, the presence of Staphylococcus aureus, and coliform counts of 290 bulk tank milk samples from March 2009 to May $2011^{1}$

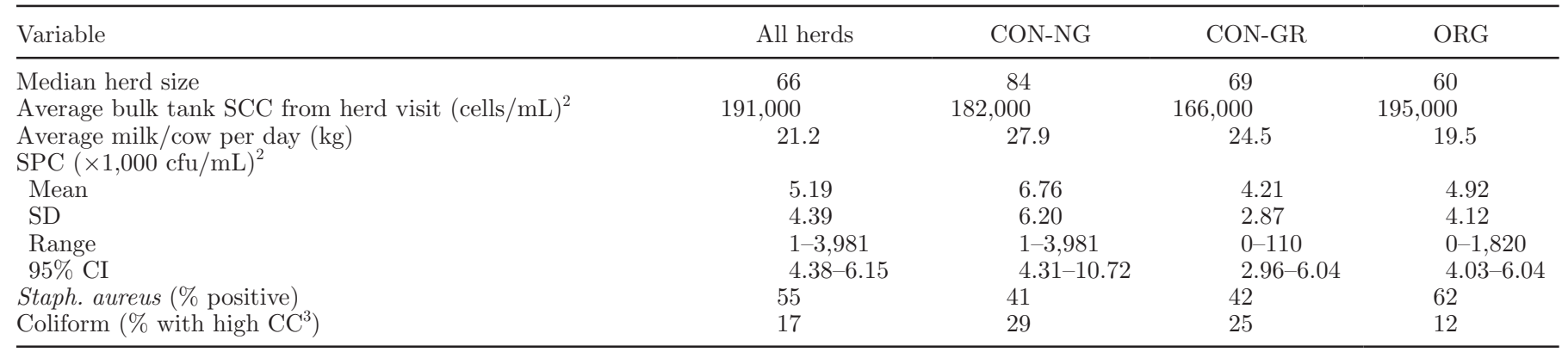

${ }^{1}$ Samples were from conventional nongrazing $(\mathrm{CON}-\mathrm{NG} ; \mathrm{n}=63)$, conventional grazing $(\mathrm{CON}-\mathrm{GR} ; \mathrm{n}=36)$, and organic $(\mathrm{ORG} ; \mathrm{n}=191)$ dairy farms in New York, Oregon, and Wisconsin.

${ }^{2}$ Values shown are the geometric mean of the log-transformation.

${ }^{3}$ High coliform counts (CC) are defined as bulk tanks with coliform counts $\geq 50 \mathrm{cfu} / \mathrm{mL}$. 
a preliminary backward stepwise regression was performed for each group, and variables that were significant at $P \leq 0.25$ in those groups remained. Variables that were selected for final model inclusion before backward stepwise regression were milk production per cow per day, average reported SCC, estimated calving interval, mean BCS, written treatments, transferring cows, number of milkers, and the EIS.

Backward stepwise logistic regression modeling resulted in a model that, in addition to the forced design variables (grazing system, herd size category, and location), associated 4 predictor variables with LSPC (Table 2). A higher average reported SCC was associated with an increased LSPC $(P=0.004)$. Higher milk production was associated with a lower LSPC $(P<$ 0.001). Farms that had a lower bulk tank LSPC tended to have cows with a higher mean BCS $(P=0.001)$. As the number of milkers on the farm increased, the LSPC increased.

Final SPC Organic Herd Model. A total of 18 variables were significant at $P \leq 0.25$ in the univariate analysis. After grouping the variables as general farm characteristics, management characteristics, or grazing-specific characteristics, a preliminary backward stepwise regression was performed for each group, and variables that were significant at $P \leq 0.25$ in those groups remained. Variables that were selected for final model inclusion before backward stepwise regression were age of housing, years in the dairy industry, milk production, average reported SCC, percent of problem breeders, mean BCS, mean udder hygiene score, mean hock score, use of a segregation unit, number treating mastitis cases, and EIS.

Backward stepwise logistic regression modeling resulted in a model that, in addition to the forced design variables (herd size category and location), associated 7 predictor variables with LSPC (Table 3). Higher mean BCS was associated with a lower LSPC, whereas a higher mean udder hygiene score was associated with a higher LSPC. Use of a segregation unit or a bucket milker for milking mastitis cows was associated with a lower LSPC. As the number of people on the farm treating mastitis increased, the LSPC increased. Higher milk production was associated with a decrease in LSPC $(P=0.001)$. A higher LSPC was associated with a higher average reported SCC $(P=0.002)$.

\section{Staphylococcus aureus}

Final Staph. aureus Total Herd Model. A total of 22 variables were significant at $P \leq 0.25$ in the univariate analysis. After grouping the variables as either general farm characteristics or management characteristics, a preliminary backward stepwise regression was performed for each group and variables that were significant at $P \leq 0.25$ in those groups remained. Variables that were selected for final model inclusion before backward stepwise regression were the average reported SCC, the percentage of first-lactation cows on the farm, the age of housing, the mean hock score, primary milking facility, use of automatic take offs, the number of people treating mastitis, regular veterinarian visits, the percentage of cows with 3 or fewer teats, and feeding a TMR.

Backward stepwise logistic regression modeling resulted in a model that, in addition to the forced design variables (grazing system, herd size category, and location), associated 6 predictor variables with a bulk tank that were cultures positive for Staph. aureus (Table 4). A positive Staph. aureus bulk tank milk culture

Table 2. Final total herd linear regression model showing the association of significant variables $(P \leq 0.10)$ and the bulk tank SPC (cfu/mL) on conventional and organic dairy farms ${ }^{1}$

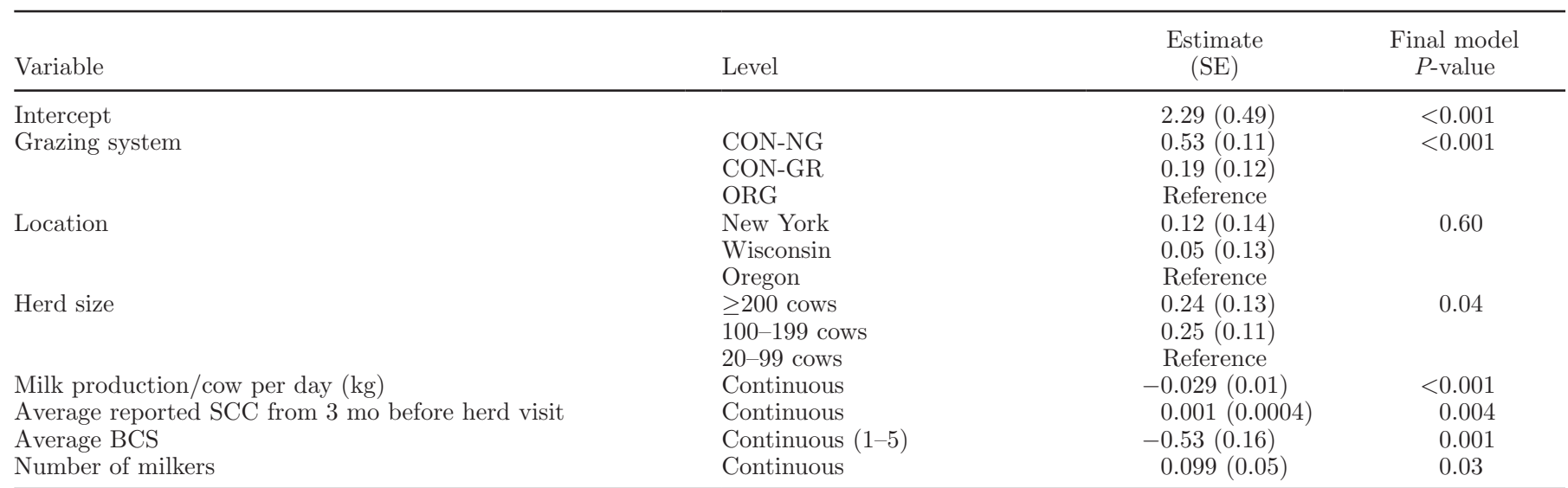

${ }^{1}$ Twenty-five farms were excluded due to missing data. Grazing system [conventional nongrazing (CON-NG; $\left.\mathrm{n}=59\right)$, conventional grazing $(\mathrm{CON}-\mathrm{GR} ; \mathrm{n}=35)$, and organic $(\mathrm{ORG} ; \mathrm{n}=173)]$, location, and herd size were included in the model as design variables. 
Table 3. Final organic herd linear regression model showing the association of significant variables $(P \leq 0.10)$ and the bulk tank SPC (cfu/ $\mathrm{mL})$ on organic farms $(\mathrm{n}=173)^{1}$

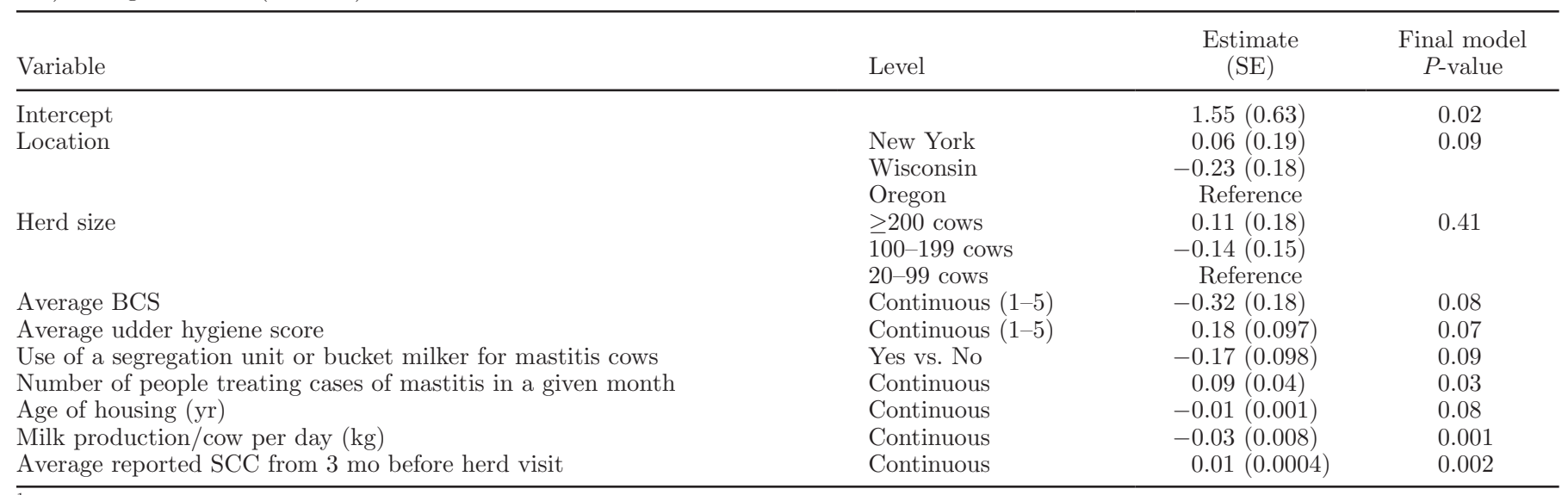

${ }^{1}$ Twenty-one farms were excluded due to missing data. Location and herd size were included in the model as design variables.

result was associated with a higher reported SCC $(P$ $<0.001)$, a lower percentage of first-lactation cows on the farm, older housing $(P=0.01)$, a higher mean hock score of scored adult animals, a lower likelihood of using automatic takeoffs, and a higher percentage of the herd with 3 or fewer teats.

Final Staph. aureus Organic Herd Model. A total of 24 variables were significant at $P \leq 0.25$ in the univariate analysis. After grouping the variables as general farm characteristics, management characteristics, or grazing-specific characteristics, a preliminary backward stepwise regression was performed for each group, and variables that were significant at $P \leq 0.25$ in those groups remained. Variables that were selected for inclusion before backward stepwise regression were the average reported SCC, age of housing, primary milking facility, use of automatic take offs, number of milking units, mean BCS, mean hock score, any use of AI in nonlactating heifers, regular veterinarian visits, percentage of the herd with 3 or fewer teats, number of people treating mastitis, and transferring cows to an alternate farm.

Backward stepwise logistic regression modeling resulted in a model that, in addition to the forced design variables (size category and location), associated 4 predictor variables with a bulk tank that cultured positive for Staph. aureus (Table 5). A positive Staph. aureus bulk tank milk culture result was associated with a higher reported SCC $(P<0.001)$, older housing for adult animals, a higher percentage of the herd with 3

Table 4. Final total herd logistic regression model showing the association of significant variables $(P \leq 0.10)$ and bulk tanks that had Staphylococcus aureus cultured on conventional and organic farms ${ }^{1}$

\begin{tabular}{|c|c|c|c|c|c|}
\hline Variable & Level & $\begin{array}{l}\beta \text { coefficient } \\
(\mathrm{SE})\end{array}$ & $\begin{array}{l}\text { Odds } \\
\text { ratio }^{2}\end{array}$ & $\begin{array}{l}95 \% \text { odds ratio } \\
\text { confidence limit }\end{array}$ & $\begin{array}{c}\text { Final model } \\
P \text {-value }\end{array}$ \\
\hline Intercept & & $-3.42(1.13)$ & & & 0.002 \\
\hline Grazing system & $\mathrm{CON}-\mathrm{NG}$ & $-0.68(0.40)$ & 0.51 & $0.23-1.10$ & 0.19 \\
\hline \multirow{2}{*}{ Location } & New York & $0.73(0.55)$ & 2.07 & $0.70-6.08$ & 0.36 \\
\hline & Wisconsin & $0.76(0.54)$ & 2.14 & $0.74-6.20$ & \\
\hline \multirow{2}{*}{ Herd size } & $100-199$ cows & $-0.23(0.47)$ & 0.80 & $0.32-2.02$ & \\
\hline & 20-99 cows & Reference & & & \\
\hline Average reported SCC & Continuous & $0.007(0.001)$ & 1.01 & $1.00-1.01$ & $<0.001$ \\
\hline Percent of first-lactation cows & Continuous & $-0.03(0.014)$ & 0.97 & $0.94-0.99$ & 0.02 \\
\hline Age of housing & Continuous & $0.01(0.004)$ & 1.01 & $1.00-1.02$ & 0.01 \\
\hline Mean hock score & Continuous & $1.63(0.67)$ & 5.11 & $1.37-18.99$ & 0.02 \\
\hline Use of automatic takeoffs & Yes vs. No & $-0.62(0.34)$ & 0.54 & $0.28-1.04$ & 0.07 \\
\hline
\end{tabular}

${ }^{1}$ Twenty-five farms were excluded due to missing data. Grazing system [conventional nongrazing $(\mathrm{CON}-\mathrm{NG} ; \mathrm{n}=59)$, conventional grazing $(\mathrm{CON}-\mathrm{GR} ; \mathrm{n}=35)$, and organic $(\mathrm{ORG} ; \mathrm{n}=173)]$, location, and herd size were included in the model as design variables.

${ }^{2}$ Odds of having a Staphylococcus aureus positive bulk tank. 
Table 5. Final organic herd logistic regression model showing the association of significant variables $(P \leq 0.10)$ and bulk tanks that had Staphylococcus aureus cultured on organic farms $(\mathrm{n}=173)^{1}$

\begin{tabular}{|c|c|c|c|c|c|}
\hline Variable & Level & $\begin{array}{l}\beta \text { coefficient } \\
\quad(\mathrm{SE})\end{array}$ & $\begin{array}{l}\text { Odds } \\
\text { ratio }^{2}\end{array}$ & $\begin{array}{l}95 \% \text { odds ratio } \\
\text { confidence limit }\end{array}$ & $\begin{array}{c}\text { Final model } \\
P \text {-value }\end{array}$ \\
\hline Intercept & & $-2.91(0.97)$ & & & 0.003 \\
\hline \multirow{2}{*}{ Location } & Wisconsin & $0.60(0.71)$ & 1.83 & $0.46-7.33$ & \\
\hline & Oregon & Reference & & Reference & \\
\hline \multirow[t]{2}{*}{ Herd size } & $\geq 200$ cows & $0.35(0.68)$ & 1.41 & $0.37-5.41$ & 0.78 \\
\hline & 100-199 cows & $-0.20(0.59)$ & 0.82 & $0.26-2.58$ & \\
\hline Age of housing & Continuous & $0.01(0.002)$ & 1.01 & $1.00-1.02$ & 0.03 \\
\hline Percentage of the herd with 3 or fewer teats & Continuous & $0.08(0.04)$ & 1.08 & $1.01-1.16$ & 0.03 \\
\hline $\begin{array}{l}\text { Number of people treating mastitis in a typical } \\
\text { month }\end{array}$ & Continuous & $-0.32(0.16)$ & 0.73 & $0.53-1.00$ & 0.05 \\
\hline
\end{tabular}

${ }^{1}$ Twenty-one farms were excluded due to missing data. Location and herd size were included in the model as design variables.

${ }^{2}$ Odds of having a Staphylococcus aureus positive bulk tank.

or fewer teats, and fewer people on the farm treating mastitis.

\section{Coliform Count}

Final Total Herd Coliform Model. A total of 15 variables were significant at $P \leq 0.25$ in the univariate analysis. After grouping the variables as either general farm characteristics or management characteristics, a preliminary backward stepwise regression was performed for each group and variables that were significant at $P \leq 0.25$ in those groups remained. Variables that were selected for inclusion before backward stepwise regression were age of housing, years dairying, the presence of Staph. aureus, average reported SPC, average reported SCC, mean udder hygiene score, any use of $\mathrm{AI}$ in nonlactating heifers, use of gloves during milking, feeding a TMR, and the number of milkers on the farm.

Backward stepwise logistic regression modeling resulted in a model that, in addition to the forced design variables (size category, grazing system, and location), associated 4 predictor variables with a bulk tank that had a high CC (Table 6). Any use of AI in nonlactating heifers was associated with a lower CC. Feeding TMR was associated with a high CC. High CC was associated with a lesser likelihood of culturing Staph. aureus from the bulk tank $(P=0.01)$. High $C \mathrm{C}$ was also associated with higher reported SCC $(P<0.001)$.

Final Organic Herd Coliform Model. A total of 16 variables were significant at $P \leq 0.25$ in the univariate analysis. After grouping the variables as general farm characteristics, management characteristics, or grazing-specific characteristics, a preliminary

Table 6. Final total herd logistic regression model showing the association of significant variables $(P \leq 0.10)$ and bulk tanks that had a high coliform count $(\geq 50 \mathrm{cfu} / \mathrm{mL})^{1}$

\begin{tabular}{|c|c|c|c|c|c|}
\hline Variable & Level & $\begin{array}{l}\beta \text { coefficient } \\
(\mathrm{SE})\end{array}$ & $\begin{array}{l}\text { Odds } \\
\text { ratio }^{2}\end{array}$ & $\begin{array}{l}95 \% \text { odds ratio } \\
\text { confidence limit }\end{array}$ & $\begin{array}{c}\text { Final model } \\
P \text {-value }\end{array}$ \\
\hline Intercept & & $-3.61(0.87)$ & & & $<0.001$ \\
\hline \multirow{2}{*}{ Grazing system } & CON-NG & $0.92(0.47)$ & 2.51 & $1.01-6.24$ & 0.03 \\
\hline & ORG & Reference & & Reference & \\
\hline \multirow[t]{2}{*}{ Location } & New York & $-0.27(0.73)$ & 0.76 & $0.19-3.16$ & 0.22 \\
\hline & Wisconsin & $0.52(0.68)$ & 1.69 & $0.45-6.40$ & \\
\hline \multirow{2}{*}{ Herd size } & $\overline{100}-199$ cows & $-0.38(0.60)$ & 0.69 & $0.21-2.24$ & \\
\hline & 20-99 cows & Reference & & Reference & \\
\hline Any use of AI in nonlactating heifers & Yes vs. No & $-1.00(0.43)$ & 0.37 & $0.16-0.86$ & 0.02 \\
\hline Feeding a TMR & Yes vs. No & $0.79(0.45)$ & 2.20 & $0.91-5.33$ & 0.08 \\
\hline Presence of Staph. aureus in the bulk tank & Yes vs. No & $-1.00(0.40)$ & 0.37 & $0.17-0.81$ & 0.01 \\
\hline Average reported SCC & Continuous & $0.01(0.01)$ & 1.01 & $1.00-1.01$ & $<0.001$ \\
\hline
\end{tabular}

${ }^{1}$ Twenty-five farms were excluded due to missing data. Grazing system [conventional nongrazing $(\mathrm{CON}-\mathrm{NG} ; \mathrm{n}=59)$, conventional grazing $(\mathrm{CON}-\mathrm{GR} ; \mathrm{n}=35)$, and organic (ORG; $\mathrm{n}=173)]$, location, and herd size were included in the model as design variables.

${ }^{2}$ Odds of having a high coliform count in the bulk tank $(\geq 50 \mathrm{cfu} / \mathrm{mL})$. 
backward stepwise regression was performed for each group, and variables that were significant at $P \leq 0.25$ in those groups remained. Variables that were selected for inclusion before backward stepwise regression were the primary milking facility, mean udder hygiene score, age of housing, number of years in the dairy industry, average reported SPC, average reported SCC, percent of first-lactation cows on the farm, any use of $\mathrm{AI}$ in nonlactating heifers, use of a written record of all treatments, the number of milkers on the farm, feeding a TMR, and use of a nutritionist.

Backward stepwise logistic regression modeling resulted in a model that, in addition to the forced design variables (size category and location), associated 8 predictor variables with a high bulk tank CC (Table 7). Lower $\mathrm{CC}$ was associated with any use of $\mathrm{AI}$ in nonlactating heifers, having a written record of treatments, and using a nutritionist. As the age of housing and the number of years spent dairying increased, the $\mathrm{CC}$ also increased. High $\mathrm{CC}$ was also associated with higher average reported SPC, a lower percentage of first-lactation cows on the farm, and feeding a TMR $(P=0.003)$.

\section{Alternative Models}

A common variable through all the models, with the exception of the organic CC model, was the average reported SCC from 3 mo before the herd visit. With the exception of the total herd CC model, we found no significant changes in the remaining models. In the total herd CC model, when SCC was removed, the use of gloves during milking, the number of years in the dairy industry and average reported SPC remained in the model, all of which are risk factors for high SCC. Therefore, SCC was left in as a predictor variable for all models except the total herd CC model. Figure 1 shows the association of the bulk tank $\log _{10}$ SCC $(\times 1,000$ cells $/ \mathrm{mL})$ with LSPC $(\times 1,000 \mathrm{cfu} / \mathrm{mL})$, indicating that a low SCC and low SPC have a clear relationship. The relationships of SCC with the presence of Staph. aureus (Figure 2) and CC (Figure 3) were also determined to be strongly associated, as high CC and the presence of Staph. aureus were both related to a higher SCC $(P<$ 0.001 and $P<0.001$, respectively).

\section{DISCUSSION}

This study was an element of a larger project with the principal goal of assessing the management practices, herd health, and characteristics of conventional and organic dairy farms in New York, Oregon, and Wisconsin. The purpose of this report is to determine the effect of selected management variables on bulk tank SPC, CC, and Staph. aureus presence in the bulk tank.

All ORG farms in our study were matched with CON farms of similar size and location, allowing comparisons to be as precise as possible. A varied range of management methods, and consequently milk quality results, are represented in our population. We visited approximately $30 \%$ of the total number of organic dairy farms across the 3 states, representing a large portion of the organic dairy industry. This study was primarily a cross-sectional study, and we recognize that this method of data collection and research has limitations. Although the study has solid internal validity,

Table 7. Final organic herd logistic regression model showing the association of significant variables $(P \leq 0.10)$ and bulk tanks that had a high coliform count $(\geq 50 \mathrm{cfu} / \mathrm{mL})$ in the organic population $(\mathrm{n}=173)^{1}$

\begin{tabular}{|c|c|c|c|c|c|}
\hline Variable & Level & $\begin{array}{c}\beta \text { coefficient } \\
(\mathrm{SE})\end{array}$ & $\begin{array}{l}\text { Odds } \\
\text { ratio }^{2}\end{array}$ & $\begin{array}{l}95 \% \text { odds ratio } \\
\text { confidence limit }\end{array}$ & $\begin{array}{c}\text { Final model } \\
P \text {-value }\end{array}$ \\
\hline Intercept & & $-0.58(1.76)$ & & & 0.74 \\
\hline \multirow[t]{2}{*}{ Location } & New York & $-0.42(1.13)$ & 0.66 & $0.17-6.00$ & 0.65 \\
\hline & Oregon & Reference & & Reference & \\
\hline \multirow[t]{2}{*}{ Herd size } & $\geq 200$ cows & $0.17(0.97)$ & 1.18 & $0.18-7.95$ & 0.27 \\
\hline & 100-199 cows & $-1.53(1.00)$ & 0.22 & $0.03-1.55$ & \\
\hline Years dairying & Continuous & $0.06(0.03)$ & 1.06 & $1.01-1.12$ & 0.03 \\
\hline \multirow[t]{3}{*}{ Mean reported SPC } & $\geq 33,000 \mathrm{cfu} / \mathrm{mL}$ & $2.32(0.93)$ & 10.24 & $1.65-63.46$ & 0.04 \\
\hline & $\overline{8}, 000-32,000 \mathrm{cfu} / \mathrm{mL}$ & $1.33(0.84)$ & 3.77 & $0.73-19.48$ & \\
\hline & $0-7,000 \mathrm{cfu} / \mathrm{mL}$ & Reference & & Reference & \\
\hline Percentage first-lactation cows & Continuous & $-0.06(0.03)$ & 0.95 & $0.90-1.00$ & 0.05 \\
\hline Any use of $\mathrm{AI}$ in nonlactating heifers & Yes vs. No & $-1.49(0.63)$ & 0.23 & $0.07-0.77$ & 0.02 \\
\hline Written record of treatments & Yes vs. No & $-1.63(0.67)$ & 0.20 & $0.05-0.73$ & 0.02 \\
\hline
\end{tabular}

${ }^{1}$ Twenty-one farms were excluded due to missing data. Location and herd size were included in the model as design variables.

${ }^{2}$ Odds of having a high coliform count in the bulk tank $(\geq 50 \mathrm{cfu} / \mathrm{mL})$. 


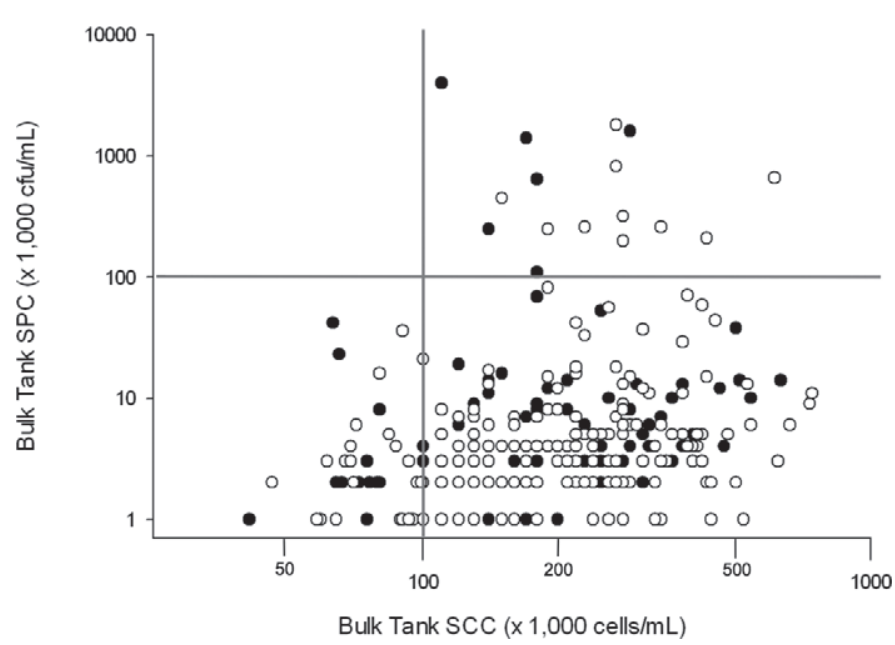

Figure 1. Scatterplot showing the relationship of bulk tank SCC $(\times 1,000$ cells $/ \mathrm{mL})$ and SPC in organic $(\mathrm{O} ; \mathrm{n}=190)$ and conventional $(\bullet ; n=100)$ dairy farms in New York, Oregon, and Wisconsin from March 2009 to May 2011. Both axes are log formatted.

interpreting the results and applying to a group outside of the study demographic should be done with care, with the study design and population in mind. The cross-sectional nature of the study does not allow us to extrapolate information about the organic industry over an extended period. In addition to this, we used a liberal significance value of $P \leq 0.10$ to glean as much information from the data set as possible. As a result of this and the large data set size, there is a greater risk of finding inaccurate results.

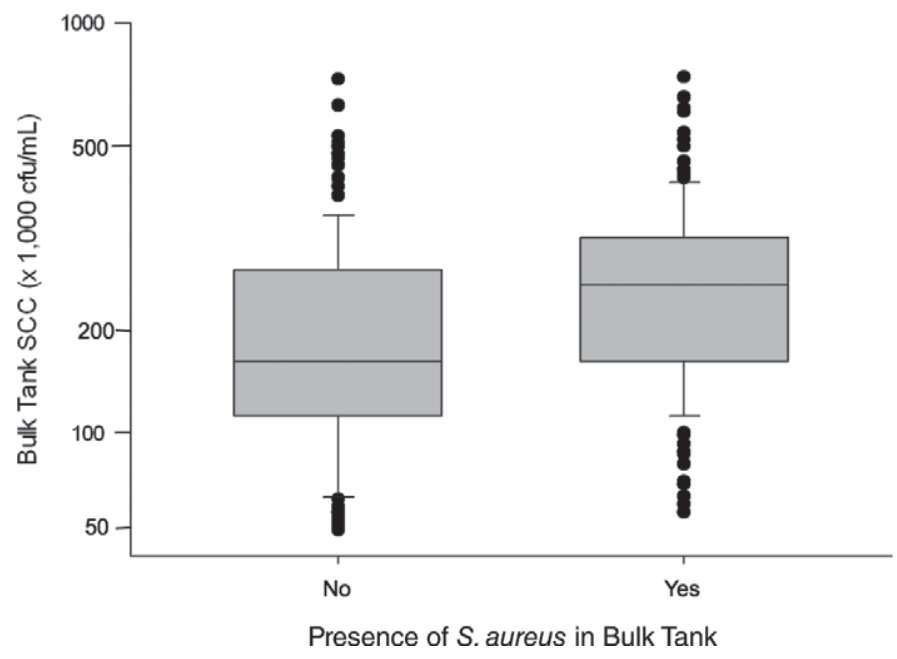

Figure 2. Box plot of the relationship between the presence of Staphylococcus aureus and the $\log _{10}$ SCC $(\times 1,000$ cells $/ \mathrm{mL})$ in the bulk tank milk of 190 organic and 100 conventional dairy farms in New York, Oregon, and Wisconsin from March 2009 to May 2011. The y-axis is formatted as a log scale. $P \leq 0.001$.

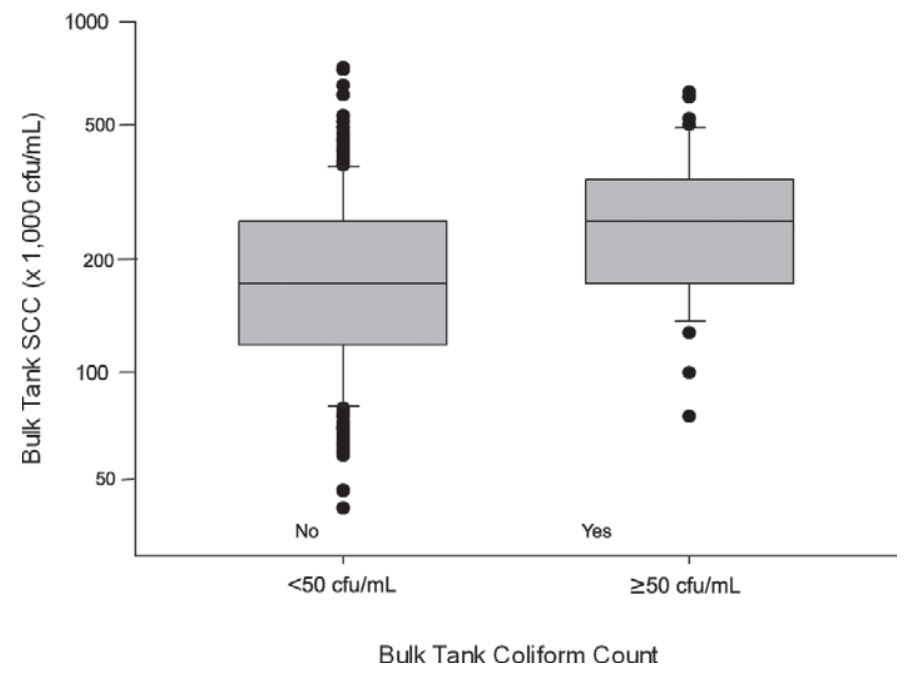

Figure 3. Box plot of the relationship between coliform counts and the SCC $(\times 1,000$ cells $/ \mathrm{mL})$ in the bulk tank milk of 190 organic and 100 conventional dairy farms in New York, Oregon, and Wisconsin from March 2009 to May 2011. Low coliform counts were defined as $<50 \mathrm{cfu} / \mathrm{mL}$, and high coliform counts were defined as $\geq 50 \mathrm{cfu} / \mathrm{mL}$. The $\mathrm{y}$-axis is formatted as a $\log$ scale. $P \leq 0.001$.

The models represented in this manuscript were built based on results from previous analysis from the same project (Cicconi-Hogan et al., 2013; Stiglbauer et al., 2013). Previously, CC and Staph. aureus were found to be different among grazing systems in univariate analyses and were natural choices for further model building. Each model had a unique set of variables that presented an association with the various outcome parameters, but general management and management precision was the overarching theme common to them all. Both the organic and total herd LSPC models presented an association of high LSPC with lower milk production, higher SCC, and lower mean BCS. High LSPC and under-conditioned cows may both be associated with inadequate management and a less clean environment. Alternatively, a higher SCC, a lower mean BCS, and low milk production may be the result of a high LSPC, as the higher bacterial counts are potentially associated with more IMI, some of which cause systemic effects, such as a decrease in body condition and milk production (Zadoks et al., 2011; De Vliegher et al., 2012). From the information gathered, the causality is uncertain. The associated increase in milkers with increase LSPC in the total herd model may be a result of inconsistency among a larger numbers of milkers, resulting in less precision or consistency in milking procedures. Similarly, previous research has shown that frequent use of part-time milkers on a farm increases the risk of residues in the milk (McEwen et al., 1991), supporting the conclusion that consistency in milking is important to milk quality. The total herd model also indicated 
that LSPC was significantly lower in the ORG population than on conventional farms. The organic LSPC model showed that the ORG community has its own challenges, as higher udder hygiene scores, more people on the farm treating or managing mastitis cases, and less usage of a segregation unit or bucket milker were associated with higher LSPC. These variables are likely indicative of the precision of management on the farm, as dirty udders, a lack of milk segregation, and possible inconsistency in treatment or management protocols among large numbers of people on the farm could cause increased bacterial load. Improvement in these areas, such as through written standard operating procedures, would likely result in a decrease in the SPC of the milk and, consequently, better milk quality.

The total herd and organic models assessing associations with the presence of Staph. aureus showed an increased SCC, older housing, and a greater percentage of adult animals with 3 or fewer teats on the farm in common. Increased SCC was associated with the presence of Staph. aureus infections, so the association was expected, and further supported by Figure 2, showing the relationship of bulk tank SCC to the presence of Staph. aureus. Compared with newer housing, older housing may be more difficult to keep clean and might be associated with older milking equipment, allowing Staph. aureus to propagate more easily. The percentage of animals with 3 or fewer teats on the farm is likely representative of a herd with a known mastitis problem that is drying off teats from specific problem animals as a form of mastitis management. In the total herd model, the association of low numbers of first-lactation animals on the farm with Staph. aureus in the bulk tank was indicative of more older animals in the herd, who are more likely to be chronically infected with Staph. aureus and more difficult to cure than their younger herdmates (Barkema et al., 2006; De Vliegher et al., 2012). Higher mean hock scores, which are representative of lesions and dirty hocks, may relate to more skin infections with Staph. aureus and transmission of these infections to the udder. The lack of automatic takeoffs was associated with presence of Staph. aureus in the model, and may indicate over-milking, which is likely without take-offs, and is related to IMI (Hillerton et al., 2002) such as Staph. aureus. The organic Staph. aureus model had only one variable that was not included in the total herd model. In the organic subset, fewer people treating mastitis on the farm was associated with the presence of Staph. aureus in the bulk tank, which may simply be a consequence of the lack of mastitis treatments for organic farms.

The total herd and organic herd coliform models shared only 2 variables. Using only natural service to breed heifers and feeding a TMR were associated with a higher $\mathrm{CC}$ in both models. Use of natural service and feeding a TMR are likely proxies for attentive management practices and use of external support, such as a nutritionist (Cicconi-Hogan et al., 2013) and not directly or causally related to an increased CC. In the total herd model, a high CC was associated with lower odds of being positive for Staph. aureus. This negative correlation between Staph. aureus and CC was not unexpected, because herds with a contagious mastitis problem due to Staph. aureus are less likely to also harbor a problem with coliform IMI (Barkema et al., 1998). Organic farms had significantly lower CC, indicating that the ORG population was not as susceptible to coliform problems as the conventional population. However, as seen in the organic CC model, it is clear that an organic population that does have coliform problems has its own set of risk factors. More years in the dairy industry has been a consistent finding in our data with regard to lower milk quality, as seen in Cicconi-Hogan et al. (2013), and we believe this is indicative of younger farmers or farmers new to the dairy industry being more assertive in their management and treatments of the herd. However, the regression coefficient is small, as we found previously, and likely does not predict a major change in CC. An increase in average reported SPC was associated with a high CC, which may be expected, because both parameters can be representative of possible contamination of the bulk tank from outside sources or from IMI. Lack of written records of treatments and not using a nutritionist are both suggestive of less precise or intensive management of the farm, which could lead to higher CC. The association of newer housing and a high CC is an unexpected outcome, and we believe that this variable ended up in the model due to chance. Although the average reported SCC did not have a clear association with high $\mathrm{CC}$ in the organic model, there was an association in the total herd model, supported further by Figure 3.

Overall, the results from this analysis, in conjunction with previous results from the project, indicate that management practices are of utmost importance to milk quality on both organic and conventional dairy farms. Additionally, bulk tank milk quality is similar across grazing systems. Somatic cell counts are associated with SPC, Staph. aureus, and CC in our models, indicating that many of the parameters used to measure milk quality are connected. It is useful to farmers to monitor several of the parameters to get an overall picture of their milk quality, which has a direct effect on the pay price of the milk, and thus, the economic success of the dairy operation. As expected, mastitis management had an effect on milk quality, because variables such as the number of people treating mastitis, udder hygiene, the number of people milking on the 
farm, and the percentage of the herd with 3 or fewer teats were a common theme across several of the models. Both organic and conventional farms could benefit from more attentive management of their mastitis cases and keeping consistent records on milk quality. Both of these suggestions would engage the farmer more fully in the health of the animals, as well as improve the bulk tank milk quality. Additionally, although several variables affect milk quality on conventional and organic farms alike, the organic demographic may use different methods and face different challenges than the conventional population.

Our research indicates that no single set of variables can predict good milk quality. However, many simple changes and management procedures can contribute to improving milk quality on a farm. Both the organic and conventional farming communities can benefit from the results of this research, as this article contains information that can be used to enhance milk quality improvement programs for the entire dairy industry.

\section{CONCLUSIONS}

The need for more research on organic dairy production and management is largely consumer driven. Although our previous research has shown that the differences between organic and conventional dairy production systems are not profound, the quest for high quality milk requires different management choices depending on the production system. No single set of variables predicted a high LSPC, the presence of Staph. aureus, or a high CC. Attention to mastitis and mastitis management was an overarching theme across most of the models, although the variables in the models were often different. The EIS score, which was found to have an effect on SCC in previous studies, did not appear to have an effect on the outcome variables presented here. The average reported SCC, however, did come out in most of the models, indicating a clear relationship between various parameters of milk quality assessment. Both the organic and conventional dairy communities could benefit from more intense mastitis management and consistent milk quality monitoring.

\section{ACKNOWLEDGMENTS}

This study was supported by US Department of Agriculture's National Institute for Food and Agriculture Integrated Organic Program grant \# 2008-5110619463, "Impact of Organic Management on Dairy Animal Health and Well-being." We thank all the farmers who participated in the study in New York, Vermont, Pennsylvania, Oregon, and Wisconsin. Special thanks to Rebecca Mitchell (Cornell University, Ithaca, NY) for her assistance with statistical analysis. The authors also recognize the efforts of the laboratories at Quality Milk Production Services at Cornell University (Ithaca, NY), Dairy One Cooperative Inc. (Ithaca, NY), and the University of Wisconsin-Madison Milk Quality Laboratory (Madison).

\section{REFERENCES}

Barkema, H. W., Y. H. Schukken, T. J. G. M. Lam, M. L. Beiboer, H. Wilmink, G. Benedictus, and A. Brand. 1998. Incidence of clinical mastitis in dairy herds grouped in three categories by bulk milk somatic cell counts. J. Dairy Sci. 81:411-419.

Barkema, H. W., Y. H. Schukken, and R. N. Zadoks. 2006. Invited review: The role of cow, pathogen, and treatment regimen in the therapeutic success of bovine Staphylococcus aureus mastitis. J. Dairy Sci. 89:1877-1895.

Cicconi-Hogan, K. M., M. Gamroth, R. Richert, P. L. Ruegg, K. E. Stiglbauer, and Y. H. Schukken. 2013. Associations of risk factors with somatic cell count in bulk tank milk on organic and conventional dairy farms in the United States. J. Dairy Sci. 96:36893702 .

De Vliegher, S., L. K. Fox, S. Piepers, S. McDougall, and H. W. Barkema. 2012. Invited review: Mastitis in dairy heifers: Nature of the disease, potential impact, prevention, and control. J. Dairy Sci. 95:1025-1040

Dohoo, I. R., W. Martin, and H. Stryhn. 2010. Veterinary Epidemiologic Research. 2nd ed. VER Inc., Prince Edward Island, Canada.

Dufour, S., A. Fréchette, H. W. Barkema, A. Mussell, and D. T. Scholl. 2011. Invited review: Effect of udder health management practices on herd somatic cell count. J. Dairy Sci. 94:563-579.

Elmoslemany, A., G. Keefe, and I. Dohoo. 2010. The association between bulk tank milk analysis for raw milk quality and on-farm management practices. Prev. Vet. Med. 95:32-40.

Ferguson, J. D., D. T. Galligan, and N. Thomsen. 1994. Principal descriptors of body condition score in Holstein cows. J. Dairy Sci. 77:2695-2703.

Food and Drug Administration. 2009. Grade "A" Pasteurized Milk Ordinance. United States Department of Health and Human Services. Silver Spring, MD. Accessed May 1, 2013. http://www.fda. gov/downloads/Food/GuidanceRegulation/UCM209789.pdf.

Fulwider, W. K., T. Grandin, D. J. Garrick, T. E. Engle, W. D. Lamm, N. L. Dalsted, and B. E. Rollin. 2007. Influence of free-stall base on tarsal joint lesions and hygiene in dairy cows. J. Dairy Sci. 90:3559-3566.

Haran, K. P., S. M. Godden, D. Boxrud, S. Jawahir, J. B. Bender, and S. Sreevatsan. 2012. Prevalence and characterization of Staphylococcus aureus, including methicillin-resistant Staphylococcus aureus, isolated from bulk tank milk from Minnesota dairy farms. J. Clin. Microbiol. 50:688-695.

Hillerton, J. E., J. W. Pankey, and P. Pankey. 2002. Effect of overmilking on teat condition. J. Dairy Res. 69:81-84.

Hogan, J., and K. L. Smith. 2003. Coliform mastitis. Vet. Res. 34:507-519.

Hogan, J. S., R. N. González, R. J. Harmon, S. C. Nickerson, S. P. Oliver, J. W. Pankey, and K. L. Smith. 1999. Laboratory Handbook on Bovine Mastitis. National Mastitis Council Inc., Verona, WI.

Jayarao, B. M., S. C. Donaldson, B. A. Straley, A. A. Sawant, N. V. Hegde, and J. L. Brown. 2006. A survey of foodborne pathogens in bulk tank milk and raw milk consumption among farm families in Pennsylvania. J. Dairy Sci. 89:2451-2458.

Jayarao, B. M., S. R. Pillai, A. A. Sawant, D. R. Wolfgang, and N. V. Hegde. 2004. Guidelines for monitoring bulk tank milk somatic cell and bacterial counts. J. Dairy Sci. 87:3561-3573.

Karns, J. S., J. S. Van Kessel, B. J. McClusky, and M. L. Perdue. 2007. Incidence of Escherichia coli $\mathrm{O} 157: \mathrm{H} 7$ and E. coli virulence factors in US bulk tank milk as determined by polymerase chain reaction. J. Dairy Sci. 90:3212-3219. 
Keefe, G. 2012. Update on control of Staphylococcus aureus and Streptococcus agalactiae for management of mastitis. Vet. Clin. North Am. Food Anim. Pract. 28:203-216.

McEwen, S. A., W. D. Black, and A. H. Meek. 1991. Antibiotic residue prevention methods, farm management and occurrence of antibiotic residue in milk. J. Dairy Sci. 74:2128-2137.

Murphy, S. C., and K. J. Boor. 2000. Trouble-shooting sources and causes of high bacteria counts in raw milk. Dairy Food Environ. Sanit. 20:606-611.

Pol, M., and P. L. Ruegg. 2007. Treatment practices and quantification of antimicrobial drug usage in conventional and organic dairy farms in Wisconsin. J. Dairy Sci. 90:249-261.

Richert, R. M., K. M. Cicconi, M. J. Gamroth, Y. H. Schukken, K. E. Stiglbauer, and P. L. Ruegg. 2013. Management factors associated with veterinary usage by organic and conventional dairy farms. J. Am. Vet. Med. Assoc. 242:1732-1743.

Rosati, A., and A. Aumaitre. 2004. Organic dairy farming in Europe. Livest. Prod. Sci. 90:41-51.

SAS Institute. 2008. SAS/STAT ${ }^{\circledR} 9.2$ Users' Guide. SAS Institute Inc., Cary, NC.

Sato, K., P. Bartlett, R. Erskine, and J. Kaneene. 2005. A comparison of production and management between Wisconsin organic and conventional dairy herds. Livest. Prod. Sci. 93:105-115.

Schreiner, D. A., and P. L. Ruegg. 2003. Relationship between udder and leg hygiene scores and subclinical mastitis. J. Dairy Sci. $86: 3460-3465$.

Schroeder, J. W. 2009. Mastitis control programs: Milk quality evaluation tools for dairy farmers. AS-1131. North Dakota State University Extension Service, Fargo.
Schukken, Y. H., D. J. Wilson, F. Welcome, L. Garrison-Tikofsky, and R. N. Gonzalez. 2003. Monitoring udder health and milk quality using somatic cell counts. Vet. Res. 34:579-596.

Stiglbauer, K. E., K. M. Cicconi-Hogan, R. Richert, P. L. Ruegg, Y. H. Schukken, and M. Gamroth. 2013. Assessment of herd management on organic and conventional dairy farms in the United States. J. Dairy Sci. 96:1290-1300.

Sundrum, A. 2001. Organic livestock farming. Livest. Prod. Sci. $67: 207-215$.

van Schaik, G., M. Lotem, and Y. H. Schukken. 2002. Trends in somatic cell counts, bacterial counts, and antibiotic residue violations in New York State during 1999-2000. J. Dairy Sci. 85:782-789.

Wehr, M., and J. Frank. 2004. Standard Methods for the Examination of Dairy Products. 17th ed. American Public Health Association, Washington, DC

Yiridoe, E., and S. Bonti-Ankomah. 2005. Comparison of consumer perceptions and preference toward organic versus conventionally produced foods: A review and update of the literature. Renew. Agric. Food Syst. 20:193-205.

Zadoks, R. N., J. R. Middleton, S. McDougall, J. Katholm, and Y. H. Schukken. 2011. Molecular epidemiology of mastitis pathogens of dairy cattle and comparative relevance to humans. J. Mammary Gland Biol. Neoplasia 16:357-372.

Zwald, A. G., P. L. Ruegg, J. B. Kaneene, L. D. Warnick, S. J. Wells, C. Fossler, and L. W. Halbert. 2004. Management practices and reported antimicrobial usage on conventional and organic dairy farms. J. Dairy Sci. 87:191-201. 